\title{
Effects of oil spill response technologies on marine microorganisms in the high Arctic
}

Pani, Marina; Köhler, Eva; Paulsen, Maria Lund; Toxværd, Kirstine Underbjerg; Lacroix, Camille; Le Floch, Stéphane; Hjorth, Morten; Nielsen, Torkel Gissel

Published in:

Marine Environmental Research

Link to article, DOI:

10.1016/j.marenvres.2019.104785

Publication date:

2019

Document Version

Peer reviewed version

Link back to DTU Orbit

Citation (APA):

Pani, M., Köhler, E., Paulsen, M. L., Toxværd, K. U., Lacroix, C., Le Floch, S., Hjorth, M., \& Nielsen, T. G. (2019). Effects of oil spill response technologies on marine microorganisms in the high Arctic. Marine Environmental Research, 151, [104785]. https://doi.org/10.1016/j.marenvres.2019.104785

\section{General rights}

Copyright and moral rights for the publications made accessible in the public portal are retained by the authors and/or other copyright owners and it is a condition of accessing publications that users recognise and abide by the legal requirements associated with these rights.

- Users may download and print one copy of any publication from the public portal for the purpose of private study or research.

- You may not further distribute the material or use it for any profit-making activity or commercial gain

- You may freely distribute the URL identifying the publication in the public portal 
See discussions, stats, and author profiles for this publication at: https://www.researchgate.net/publication/335593882

\section{Effects of oil spill response technologies on marine microorganisms in the high Arctic}

Article in Marine Environmental Research · September 2019

DOI: 10.1016/j.marenures.2019.104785

CITATION

8 authors, including:

M. Pančić

Technical University of Denmark

15 PUBLICATIONS 201 CITATIONS

SEE PROFILE

,

Maria Paulsen

Aarhus University

34 PUBLICATIONS 252 CITATIONS

SEE PROFILE

Some of the authors of this publication are also working on these related projects:

Project Marine microplastic View project

Project

Phd Project View project
165

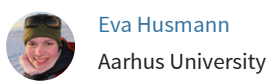

1 PUBLICATION 1 CITATION

SEE PROFILE

A Kirstine Underbjerg Toxværd

Technical University of Denmark

5 PUBlications 25 Citations

SEE PROFILE 


\title{
Effects of oil spill response technologies on marine microorganisms in the high Arctic
}

\author{
Marina Pančića ${ }^{\text {, Eva Köhler }}{ }^{\mathrm{a}, \mathrm{b}}$, Maria Lund Paulsen ${ }^{\mathrm{a}, \mathrm{c}}$, Kirstine Toxværd ${ }^{\mathrm{a}, \mathrm{d}}$, Camille Lacroix ${ }^{\mathrm{e}}$, \\ Stéphane Le Floch ${ }^{\mathrm{e}}$, Morten Hjorth ${ }^{\mathrm{d}}$, Torkel Gissel Nielsen ${ }^{\mathrm{a}, *}$ \\ ${ }^{a}$ National Institute of Aquatic Resources, Technical University of Denmark, Kemitorvet, Building 202, 2800, Kgs. Lyngby, Denmark \\ ${ }^{\mathrm{b}}$ University of Applied Sciences Bremen, Neustadswall 30, 28199, Bremen, Germany \\ ${ }^{c}$ Department of Biological Sciences, University of Bergen, Thormøhlensgate 53 A/B, 5020, Bergen, Norway \\ ${ }^{\mathrm{d}}$ Cowi Denmark, Department of Water \& Nature, Parallelvej 2, 2800, Kgs. Lyngby, Denmark \\ ${ }^{\mathrm{e}}$ CEDRE, 715 rue Alain Colas, CS 41836, 29218, Brest Cedex 2, France
}

\section{A R T I C L E I N F O}

\section{Keywords:}

Arctic microorganisms

Oil spill

Chemical dispersant

In situ burning

Natural attenuation

\begin{abstract}
A B S T R A C T
We studied how exposure to oil spill response technologies affect marine microorganisms during Arctic winter and spring. Microorganisms were exposed to chemically dispersed oil (DISP), in situ burnt oil (ISB), and natural attenuated oil (NATT) in mesocosms from February to May. We subsampled the mesocosms and studied the effects of oil in laboratory incubations as changes in biomass of the major functional groups: bacteria, heterotrophic-nanoflagellates, dinoflagellates, ciliates, pico- and nanophytoplankton, and diatoms over two 14-day periods. In winter, the majority of polycyclic aromatic hydrocarbons (PAHs) remained encapsulated in the ice, and the low concentrations of PAHs in water led to minute changes in biomass of the investigated groups. In spring, however, when the PAHs were partially released from the melting ice, the biomass of many functional groups in DISP and NATT decreased significantly, while the changes in ISB were less pronounced. The overall biomass reduction, as observed in this study, could lead to a disrupted transfer of energy from the primary producers to the higher trophic levels in oil affected areas.
\end{abstract}

\section{Introduction}

The area north of the Arctic Circle may contain around 30\% of the world's undiscovered gas and $13 \%$ of the world's unexplored oil reserves (U.S. Geological Survey, 2009). Recent retreat of the Arctic sea ice due to global warming coupled with rapid technological developments for petroleum exploration have accelerated access to the offshore Arctic regions and, thus, have improved prospects for exploration and production of oil and gas in these areas (Gautier et al., 2009).

Increasing activities in Arctic petroleum development and associated risks of oil spill accidents have led tothe development of several oil spill remediation technologies that could be applied in sub-zero environments (Wilkinson et al., 2017). The response tools considered within the contingency plans for the worst-case scenario in the Arctic include employment of chemical dispersants, in situ burning of crude oil, and natural oil weathering. In the event of an oil spill accident, however, urgent decisions must be made on how to minimize the impacts on the environment. First and foremost, the decision process includes assessment of potential impacts on various ecosystem components, for which acute (i.e. immediate) toxicity data or chronic (i.e. long-term) exposure thresholds are used (Olsen et al., 2013). The assessments based on acute toxicity tests, however, may inaccurately estimate the effects of long-term low-dose releases of oil from the sea ice and, consequently, lead to inaccurate predictions of the oil spill effects on the Arctic marine ecosystems. Therefore, chronic exposure studies in combination with acute toxicity data would enable more realistic forecasting of the consequences that oil spills and oil spill response technologies would have on the Arctic marine environments.

Given that more than $90 \%$ of all biological processes in the ocean are driven by microorganisms (Hays et al., 2005), a comprehensive understanding of how oil spills and the response technologies would affect these communities is crucial. To date, most of the few studies that

\footnotetext{
Abbreviations: DISP, chemical dispersion; ISB, in situ burning; NATT, natural attenuation; PAH, polycyclic aromatic hydrocarbon; HNF, heterotrophic nanoflagellates

* Corresponding author.

E-mail addresses: marpan@aqua.dtu.dk (M. Pančić), evakoehler89@aol.com (E. Köhler), mlp@bios.au.dk (M.L. Paulsen), kuto@cowi.dk (K. Toxværd), Camille.Lacroix@cedre.fr (C. Lacroix), Stephane.Le.Floch@cedre.fr (S. Le Floch), morh@cowi.dk (M. Hjorth), tgin@aqua.dtu.dk (T.G. Nielsen).
} 
have examined the effects of oil spills and oil spill response technologies on microbial communities have been conducted in temperate and subtropical environments. Those studies reported an increased abundance of heterotrophic bacteria exposed to different oil types and remediation treatments, indicating that the oil treatments increased the carbon pool that stimulated the growth of some bacteria (Parsons et al., 1984; Linden et al., 1987; Harayama et al., 2004; Koshikawa et al., 2007; Jung et al., 2010; Ortmann et al., 2012). Secondarily, the elevated bacterial growth resulted in increased abundances of bacterivorous heterotrophic nanoflagellates (HNF) (Parsons et al., 1984). The effects of oil spills and oil spill remediation technologies on marine phytoplankton are more equivocal. Some studies reported overall negative effects on picoplankton, nanoplankton, and diatom assemblages (Parsons et al., 1984; Harrison et al., 1986; Linden et al., 1987; Sargian et al., 2005; González et al., 2009), whereas other observed increased growth of haptophytes (Chrysochromulina sp.), chrysophytes, prasinophytes, and diatoms (Chaetoceros sp., Nitzschia sp.) (Oviatt et al., 1982; Vargo et al., 1982; Parsons et al., 1984). Only few studies reported no effect on either phytoplankton diversity or activity (Scott and Glooschenko, 1984). Although oil pollution may lead to higher mortality rates of some phytoplankton groups during first few days, their overall biomass may later increase due to decreased predation pressure (Parsons et al., 1984; Harrison et al., 1986; Linden et al., 1987; Vargo et al., 1982; Sargian et al., 2005; González et al., 2009; Abbriano et al., 2011), because even low concentrations of PAHs can have highly toxic effects on microzooplankton (Almeda et al., 2014). As microzooplankton, such as ciliates and heterotrophic dinoflagellates, are pivotal in marine food webs (Landry and Calbet, 2004), the detrimental effects of oil pollution could disrupt the structure and function of the entire microbial community and, consequently, in the transfer of carbon to higher trophic levels (Ortmann et al., 2012; Almeda et al., 2014).

The toxicity of petroleum products on Arctic microbial communities remains poorly investigated, partly due to operational constraints in the Arctic environment. As yet, few studies on effects of oil spills and the response technologies have been conducted in high-latitudes (e.g., Siron et al., 1993, 1996), with some progress in understanding the bacterial responses to oil pollution there (Delille and Siron, 1993). Because of the low biomass of bacteria and their highly selective biodegradation of oil compounds, in combination with the low evaporation losses at low temperatures, the residence time of the toxic oil compounds may be extended in sub-zero environments (Siron et al., 1993, 1996). Nevertheless, it remains unknown how phytoplankton and microzooplankton respond to oil pollution in the Arctic environment.

The current study was part of a mesocosm campaign conducted in Svalbard in 2015 (Dickins, 2017). The aim of our study was to compare the changes in biomass of the major functional groups of marine microorganisms exposed to various oil spill response technologies. We present results from two incubation microcosm studies with microbial assemblages collected from the mesocosms in March (winter; one month after adding the chemical treatments) and May (spring; three months later), whose biomasses were then assessed over a 14-day period in the controlled laboratory incubation experiments.

\section{Materials and methods}

\subsection{Field site location and mesocosm setup}

The mesocosms were deployed in Van Mijenfjorden, Svea on the west coast of Spitsbergen, Svalbard $\left(77^{\circ} 52^{\prime} 13^{\prime \prime} \mathrm{N} 16^{\circ} 44^{\prime} 44^{\prime \prime} \mathrm{E}\right)$ (Fig. 1). This industrial fjord with coal mine activities was chosen due to its geographical position that allows the sea ice to persist until late spring, as well as its accessibility by various modes of transportation from Longyearbyen to the site. Eight mesocosms were mounted and anchored in sea ice in February 2015 (Fig. 1). For detailed information regarding the mesocosms see Toxværd et al., (2018). Briefly, large holes were drilled into the ice approx. $800 \mathrm{~m}$ offshore and the mesocosms (3$\mathrm{m}$ long by $1.6 \mathrm{~m}$ diameter; $6000 \mathrm{~L}$ ) were lowered into the water in two rows approx. 20-25 $\mathrm{m}$ apart. Two control mesocosms were deployed first about $40 \mathrm{~m}$ distance from the other mesocosms to avoid contamination during application of chemicals (Fig. 1). Subsequently, chemical treatments were added to the oil mesocosms: $2 \mathrm{~L}$ of burnt oil residuals (abbreviated ISB) obtained by burning of $20 \mathrm{~L}$ of crude oil Kobbe under in situ conditions (INERIS, France); a surface slick of $20 \mathrm{~L}$ of crude oil Kobbe mixed with $1 \mathrm{~L}$ of dispersant Finasol ${ }^{\oplus}$ OSR 52 (abbreviated DISP) without any additional mixing energy (Total Fluides, Paris-La Defense, France); and 20 L of crude oil Kobbe (abbreviated NATT) ( $\sim 10 \mathrm{~L} \mathrm{~m}^{-2}$ and oil slick thickness of $0.25 \mathrm{~mm}$ ) (Toxværd et al., 2018). After treatment, ice was allowed to form naturally in all mesocosms until the samplings for laboratory incubation microcosm studies in March 2015 (winter) and May 2015 (spring).

Water sampling from the mesocosms for incubation microcosm studies was conducted on 26 March and on 14 May 2015 . Holes $(10 \mathrm{~cm}$ diameter) were drilled through the ice in each mesocosm and pipes were inserted into the ice-core holes. The pipes served as a scaffold for the pumps, to prevent contamination from oil in the ice structures, and to avoid disturbing the water column during pumping. The ice-core holes were cleaned of slush and hand-operated pumps with a rigid intake and a flexible outtake were inserted into the pipes. In order to remove any large zooplankton from the pumped water, the outtake of the pumps was covered with a $200-\mu \mathrm{m}$ mesh filter. From each mesocosm, $20 \mathrm{~L}$ of seawater was pumped (approximately $4.6 \mathrm{~L} \mathrm{~min}^{-1}$ ) from approximately $10 \mathrm{~cm}$ beneath the ice edge into 23-L insulated glass bottles to prevent freezing. The water samples were stored at $1{ }^{\circ} \mathrm{C}$ in darkness for $<12 \mathrm{~h}$ until being transported to the University Centre in Svalbard, Longyearbyen on 27 March and 15 May 2015.

\subsection{Set-up of incubation microcosms}

The 20-L water samples from each of the two control mesocosms were pooled, and from the 40-L pool, triplicate 5-L incubation control microcosms prepared and incubated for 14 days (remainder of the pooled water was discarded). The mesocosm water samples from each treatment were pooled to reduce natural variance, should that occur, in the duplicate mesocosms. The same method was applied to the $2 \times 20$ L water samples obtained from ISB, DISP, and NATT mesocosms. The microcosms were kept at $1{ }^{\circ} \mathrm{C}$, stirred manually at least twice a day, and exposed to $40-50 \mu \mathrm{mol}$ photons $\mathrm{m}^{-2} \mathrm{~s}^{-1}$ (to simulate ambient solar irradiance of $600 \mu \mathrm{mol}$ photons $\mathrm{m}^{-2} \mathrm{~s}^{-1}$, of which $<10 \%$ penetrates through $\sim 100 \mathrm{~cm}$ thick sea ice; Little et al., 1972) with a light:dark cycle of 16:8 h. The same procedure was applied in March and May. Salinity of the water samples was 33.8 in March and 31.9 in May, as measured with a VWR SympHony SP90M5 salinometer (VWR International, Inc.). The air and water temperatures were measured continuously using HOBO Data Loggers, whereas the light intensity and $\mathrm{pH}$ were measured every second day at approximately the same time using LI-COR Biosciences, model LI-1400 Data Logger (Biosciences, Lincoln, NE, USA) and Thermo Electron Corporation, Orion Star Series with a ROSS Ultra combination $\mathrm{pH}$ electrode (Thermo Electron Corporation, Beverly, MA, USA), respectively. The $\mathrm{pH}$ electrode was calibrated weekly (2-point calibration) using Thermo Electron Corporation, Orion Application Solution buffers of $\mathrm{pH} 7.0$ and 10.0 dilutions.

Subsamples $(3 \times 60 \mathrm{~mL})$ for measurements of inorganic nutrients were removed from incubation bottles and filtered through $0.2-\mu \mathrm{m}$ pore Q-Max syringe filters into acid-washed collection bottles on days $0,4,8$, and 14 . The subsamples were stored at $-80^{\circ} \mathrm{C}$ until analysis. Nitrite and nitrate $\left(\mathrm{NO}_{2}{ }^{-}+\mathrm{NO}_{3}{ }^{-}\right)$, hereafter refered to simply as nitrate), phosphate $\left(\mathrm{PO}_{4}{ }^{3-}\right)$, and silicic acid $\left(\mathrm{H}_{4} \mathrm{SiO}_{4}\right)$ were measured on a SmartChem200 wet chemistry analyzer (Unity Scientific, MA, USA), following procedures outlined for $\mathrm{NO}_{3}{ }^{-}+\mathrm{NO}_{2}{ }^{-}$(Wood et al., 1967), for $\mathrm{PO}_{4}{ }^{3-}$ (Murphy and Riley, 1962), and for $\mathrm{H}_{4} \mathrm{SiO}_{4}$ (Strickland and Parsons (1972). To determine dissolved PAH concentrations (including 

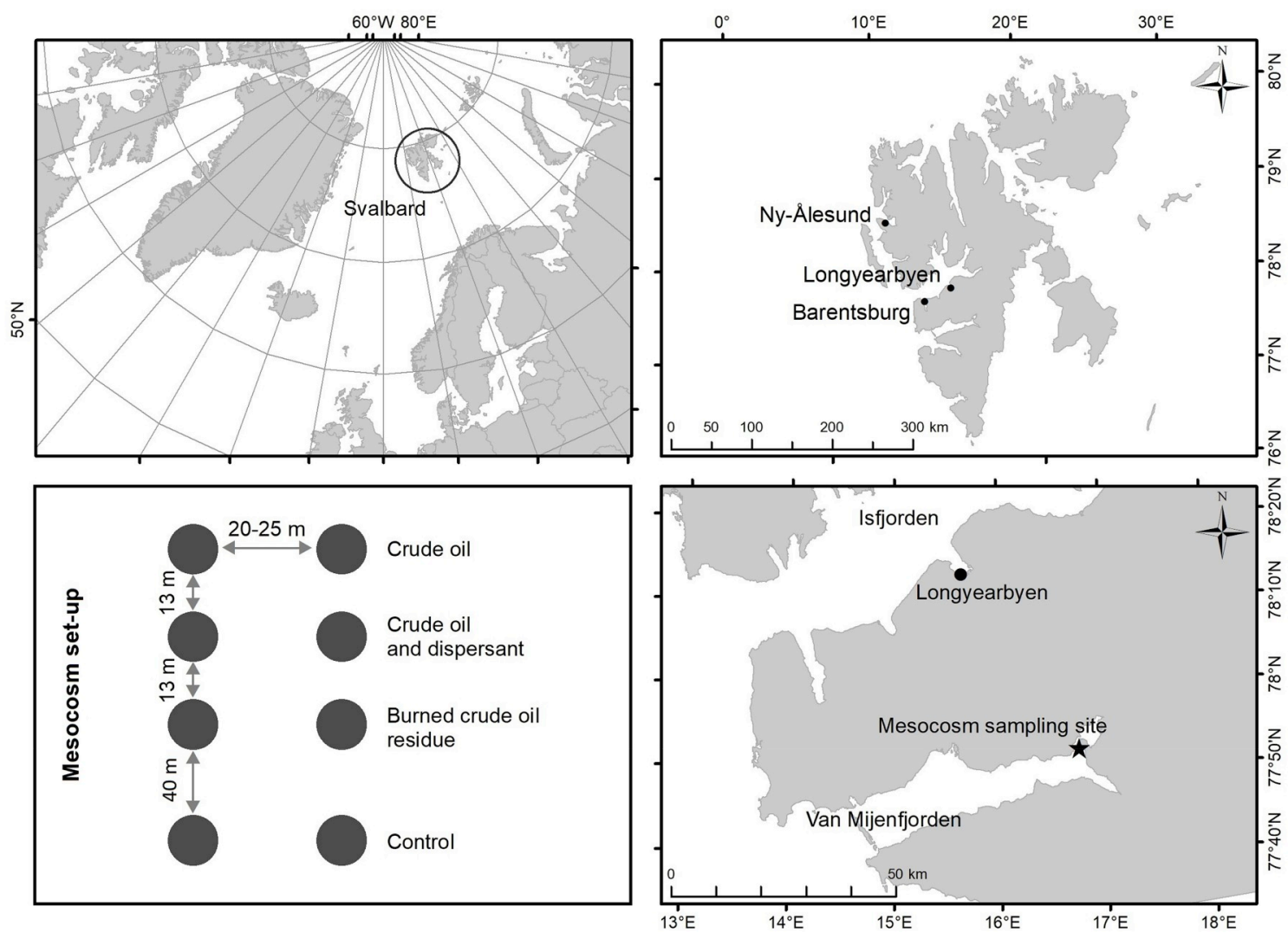

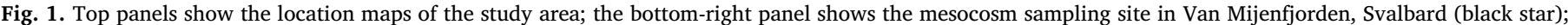
bottom-left panel shows a schematic diagram of the mesocosm set-up.

alkylated PAHs), $3 \times 100-\mathrm{mL}$ subsamples were collected from incubation bottles on days 0,8 , and 14 , and stored at $-20^{\circ} \mathrm{C}$. The total concentration of PAHs was determined according to the method described in Toxværd et al. (2018).

\subsection{Chlorophyll-a concentration}

Subsamples $(3 \times 100 \mathrm{~mL})$ for measurements of chlorophyll- $a$ concentration were taken from incubation bottles on days $0,4,8,12$, and 14 , and filtered through a $0.7-\mu \mathrm{m}$ pore size filter. The pigments were extracted in $5 \mathrm{~mL}$ of methanol (99.5\%) for $24 \mathrm{~h}$ in darkness at room temperature. The fluorescence of the extracts was measured before and after addition of $100 \mu \mathrm{L} 0.1 \mathrm{M} \mathrm{HCl}(37 \%)$ with a Turner Designs model 10-AU Fluorometer (Turner Designs, Sunnyvale, CA, USA). The fluorometer was calibrated prior to use with five dilutions of pure chlorophyll- $a$ standard (Sigma-Aldrich).

\subsection{Biomass measurements}

Subsamples were taken to determine the abundances of bacteria, small phytoplankton, and heterotrophic nanoflagellates (HNF) every second day, and diatoms and microzooplankton every fourth day, as described below.

The abundances of bacteria, small phytoplankton, and HNF were estimated using an Attune Acoustic Focusing Cytometer (Applied Biosystems by Life Technologies, CA, USA). The data were analyzed using Attune ${ }^{\circledast}$ Cytometric Software (version 2.1; Life Technologies Corporation, CA, USA). The subsamples were fixed with glutaraldehyde ( $1 \%$ final concentration) for $3 \mathrm{~h}$ in the dark at $4{ }^{\circ} \mathrm{C}$, stored at $-80^{\circ} \mathrm{C}$ until the analysis within 5 months, and thawed immediately before analysis.

The thawed bacterial aliquots $(3 \times 100 \mu \mathrm{L})$ were diluted 10 -fold in $0.2-\mu \mathrm{m}$ filtered TE buffer (Tris $10 \mathrm{mM}$, EDTA $1 \mathrm{mM}, \mathrm{pH} 8$ ) and stained with SYBR Green I (Molecular Probes Inc., Eugene, OR, USA) for $10 \mathrm{~min}$ at $80^{\circ} \mathrm{C}$ in a water bath to provide optimal staining of bacteria (Marie et al., 1999). Afterwards, the aliquots were analyzed at a $100 \mu \mathrm{Lmin}^{-1}$ flow rate on an Attune Acoustic Focusing Cytometer (Applied Biosystems by Life Technologies, CA, USA), with the discriminator set depending on their side scatter (proportional to cell size) and pigment (green and red fluorescence). Fluorescent yellow-green microspheres with diameters of $2-\mu \mathrm{m}$ (FluoSpheres ${ }^{\circledR}$ CarboxylateModified Microspheres, UK) were added to the aliquots as an internal standard. The abundance of bacteria was used for the biomass estimates based on the carbon conversion factor for bacteria (Lee and Fuhrman, 1987) (Appendices A and B).

The small phytoplankton aliquots $(3 \times 400 \mu \mathrm{L})$ were analyzed directly after thawing at a flow rate of $200 \mu \mathrm{L} \mathrm{min}^{-1}$ on the cytometer with the discriminator set depending on their side scatter (proportional to cell size) and pigment (red and orange fluorescence) (Paulsen et al., 2015).

The thawed HNF aliquots ( $1.4 \mathrm{~mL}$ ) were stained with SYBR Green I (Molecular Probes Inc., Eugene, OR, USA) for $4-6 \mathrm{~h}$ at $4{ }^{\circ} \mathrm{C}$ in the dark. The aliquots were enumerated at a flow rate of $500 \mu \mathrm{L} \mathrm{min}^{-1}$, and HNF discriminated from autotrophs and bacteria based on their pigment, i.e., red (from Chl-a) vs. green (from SYBR Green I) fluorescence. Fluorescent yellow-green microspheres with diameters of $0.5-\mu \mathrm{m}$ (FluoSpheres ${ }^{\circledast}$ Carboxylate-Modified Microspheres, UK) were added to the aliquots as an internal standard (Zubkov et al., 2007). 
To obtain the size estimates of small phytoplankton and HNF, 15-mL subsamples were additionally filtered through 8-, 5-, 3-, 2-, and 1- $\mu \mathrm{m}$ pore size filters. The size fractionation and the subsequent cell enumeration were implemented in order to assess the percentages of the various phytoplankton and HNF groups within the given size intervals (Zubkov et al., 1998; Paulsen et al., 2015). The flow rates and discriminators for small phytoplankton and HNF were set as described above. The abundances of small phytoplankton and HNF within the different size intervals were converted to the weighted arithmetic mean sizes, and used for the biomass estimates based on the carbon conversion factors (Børsheim and Bratbak, 1987; Søndergaard, 1991) (Appendices A and B).

Microzooplankton (ciliates and dinoflagellates) and diatom subsamples $(3 \times 110 \mathrm{~mL})$ were fixed with acidified Lugol solution $(3 \%$ final concentration) and stored in the dark until analysis. The subsamples were settled in Utermöhl sedimentation chambers and examined under 200-times magnification of an inverted microscope (Leica DM IL LED, Leica Microsystems GmbH, Wetzlar, Germany). Based on the gross morphology, ciliates and dinoflagellates were enumerated and divided into $10-\mu \mathrm{m}$ size classes of equivalent spherical diameter (ESD). The ESD of every specimen was measured and the cellular volume determined using the appropriate geometric shape. The cellular volume was converted to biomass using specific carbon conversion factors (Putt and Stoecker, 1989; Verity and Lagdon, 1984; Menden-Deuer and Lessard, 2000) (Appendices A and B). Loricate and aloricate ciliates, and thecate and athecate dinoflagellates were differentiated.

To summarize the sampling schedule during the two 14day incubation experiments (March and May): $\mathrm{pH}$, temperature, light, bacteria, HNF, and phytoplankton were examined every other day; nutrients, chlorophyll- $a$, and microzooplankton were examined every fourth day; PAHs were examined in the beginning, middle, and end of the experiments.

\subsection{Statistical analysis}

Repeated measures analysis of variance (rANOVA) was conducted to compare chlorophyll- $a, \mathrm{pH}$, nutrients, PAHs, and biomass of organisms among the incubated treatments. If ANOVAs were significant, pairwise comparisons of pooled standard deviations using Benjamini and Hochberg's test of variability were performed. All data were normally distributed (Shapiro-Wilk test) and did not require transformations. The homogeneity of variances was tested using Levene's test. These analyses were performed in RStudio, and the level of significance used was 0.05 .

\section{Results}

\subsection{Abiotic factors in winter}

In order to compare the effects of exposure to oil spill response technologies on marine microorganisms in winter, the first microcosm incubation experiment was performed in the laboratory with water samples collected from the mesocosms one month after the addition of chemical treatments. During this microcosm experiment, temperature, salinity, light intensity, and $\mathrm{pH}$ differed little between the treatments. Although $\mathrm{pH}$ increased in all treatments during the experiment (Table 1), no significant differences in $\mathrm{pH}$ were found among the treatments (Appendix E). The water temperature remained stable over time, averaging $1.05 \pm 0.26^{\circ} \mathrm{C}$. Salinity measured 33.8 and the light intensity at the water surface in the experimental bottles was $55 \pm 12 \mu \mathrm{mol}$ photons $\mathrm{m}^{-1} \mathrm{~s}^{-1}$.

The concentration of inorganic nutrients (nitrate and phosphate, but not silicate) generally decreased in all treatments during the experiments (Table 1); however, no significant differences were found among the treatments for any of the nutrients (Appendix E). Concentrations of polycyclic aromatic hydrocarbons (PAHs) also decreased over time in all treatments (Table 1) and differed significantly among the treatments ( $\mathrm{p}<0.05$ ). The concentrations of PAHs were significantly higher in DISP and NATT than in the control and ISB ( $p<0.05$ ), but DISP and NATT did not differ significantly from each other, nor did the control and ISB (Appendix E). Detailed information on the compositions and concentrations of PAHs and alkylated PAHs can be found in Appendix C.

\subsection{Abiotic factors in spring}

The second laboratory microcosm incubation experiment was performed with water samples collected from the mesocosms in May three months after the addition of chemical treatments. During the microcosm experiment, temperature, salinity, and light intensity differed little among the treatments, averaging $1.04 \pm 0.26^{\circ} \mathrm{C}, 31.9$, and $57 \pm 8 \mu \mathrm{mol}$ photons $\mathrm{m}^{-1} \mathrm{~s}^{-1}$, respectively. The $\mathrm{pH}$ levels decreased in all treatments over time (Table 2). Significant differences in $\mathrm{pH}$ were found among the treatments $(\mathrm{p}<0.05)$ and between all treatments (lower) than in the control. Significant differences were also found among the oil treatments ( $p<0.05$ ), except for the pair ISB-NATT (Appendix F)

Overall, the concentration of nutrients and PAHs decreased in all treatments during the experiments (Table 2). Nutrient concentrations differed significantly among the treatments $(p<0.05)$. The nitrate concentration was significantly lower in the control group than in DISP and NATT $(\mathrm{p}<0.05)$. Significant differences also were found between all other treatment pairs $(\mathrm{p}<0.05)$, except between the control and ISB (Appendix F), with the highest concentration of nitrate measured in NATT, followed by DISP, and finally by ISB and the control. Similarly, the phosphate concentration was significantly lower in the control group than in the other groups $(\mathrm{p}<0.05)$. Differences were significant between all the other treatment pairs ( $p<0.05)$, except between ISB and DISP (Appendix F). The highest concentration of phosphate was measured in NATT, followed by DISP and ISB and, lastly, by the control group. Finally, the concentration of silicate was also significantly higher

Table 1

The average concentrations $\pm \mathrm{SD}$ of $\mathrm{pH}$, nutrients (nitrate, phosphate, silicate; $\mu \mathrm{mol} \mathrm{L}^{-1}$ ), and PAH (ng L ${ }^{-1}$ ) on Days 0 and 14 in the control, burnt oil (ISB), dispersed oil (DISP), and crude oil (NATT) treatments in winter (March).

\begin{tabular}{|c|c|c|c|c|c|c|}
\hline \multirow[t]{2}{*}{ Treatment } & \multirow[t]{2}{*}{ Day } & \multicolumn{5}{|c|}{ Concentrations in winter } \\
\hline & & $\mathrm{pH}$ & Nitrate & Phosphate & Silicate & РAH \\
\hline \multirow[t]{2}{*}{ Control } & Day 0 & $7.56 \pm 0.00$ & $7.59 \pm 0.69$ & $0.55 \pm 0.07$ & $4.74 \pm 0.24$ & $100 \pm 123$ \\
\hline & Day 14 & $7.68 \pm 0.03$ & $6.21 \pm 0.37$ & $0.32 \pm 0.07$ & $4.24 \pm 0.59$ & $55 \pm 62$ \\
\hline \multirow[t]{2}{*}{ ISB } & Day 0 & $7.56 \pm 0.00$ & $7.34 \pm 0.58$ & $0.40 \pm 0.08$ & $3.87 \pm 0.19$ & $65 \pm 19$ \\
\hline & Day 14 & $7.65 \pm 0.02$ & $6.36 \pm 0.54$ & $0.36 \pm 0.06$ & $4.83 \pm 0.67$ & $35 \pm 18$ \\
\hline \multirow[t]{2}{*}{ DISP } & Day 0 & $7.61 \pm 0.00$ & $7.00 \pm 0.39$ & $0.45 \pm 0.21$ & $4.36 \pm 0.56$ & $624 \pm 39$ \\
\hline & Day 14 & $7.63 \pm 0.02$ & $5.45 \pm 0.21$ & $0.29 \pm 0.15$ & $4.68 \pm 0.98$ & $311 \pm 85$ \\
\hline \multirow[t]{2}{*}{ NATT } & Day 0 & $7.61 \pm 0.00$ & $6.70 \pm 0.96$ & $0.48 \pm 0.04$ & $4.08 \pm 0.22$ & $615 \pm 275$ \\
\hline & Day 14 & $7.65 \pm 0.01$ & $5.68 \pm 0.80$ & $0.35 \pm 0.17$ & $4.42 \pm 0.31$ & $249 \pm 33$ \\
\hline
\end{tabular}


Table 2

The average concentrations $\pm \mathrm{SD}$ of $\mathrm{pH}$, nutrients (nitrate, phosphate, silicate; $\mu \mathrm{mol} \mathrm{L}^{-1}$ ), and PAH (ng L ${ }^{-1}$ ) on Day 0 and Day 14 in the control, burnt oil (ISB), dispersed oil (DISP), and crude oil (NATT) treatments in spring.

\begin{tabular}{|c|c|c|c|c|c|c|}
\hline \multirow[t]{2}{*}{ Treatment } & \multirow[t]{2}{*}{ Day } & \multicolumn{5}{|c|}{ Concentrations in spring } \\
\hline & & $\mathrm{pH}$ & Nitrate & Phosphate & Silicate & PAH \\
\hline \multirow[t]{2}{*}{ Control } & Day 0 & $7.65 \pm 0.00$ & $5.32 \pm 0.96$ & $0.24 \pm 0.04$ & $3.40 \pm 0.67$ & $90 \pm 70$ \\
\hline & Day 14 & $7.58 \pm 0.03$ & $4.33 \pm 0.36$ & $0.26 \pm 0.03$ & $3.18 \pm 0.15$ & $27 \pm 15$ \\
\hline \multirow[t]{2}{*}{ ISB } & Day 0 & $7.63 \pm 0.00$ & $5.94 \pm 0.66$ & $0.45 \pm 0.07$ & $3.88 \pm 0.54$ & $261 \pm 62$ \\
\hline & Day 14 & $7.49 \pm 0.03$ & $4.51 \pm 0.11$ & $0.31 \pm 0.08$ & $2.88 \pm 0.17$ & $59 \pm 51$ \\
\hline \multirow[t]{2}{*}{ DISP } & Day 0 & $7.60 \pm 0.00$ & $6.47 \pm 0.13$ & $0.45 \pm 0.03$ & $3.76 \pm 0.17$ & $20,269 \pm 4,219$ \\
\hline & Day 14 & $7.47 \pm 0.02$ & $5.19 \pm 0.07$ & $0.34 \pm 0.01$ & $2.86 \pm 0.00$ & $9,519 \pm 3,620$ \\
\hline \multirow[t]{2}{*}{ NATT } & Day 0 & $7.62 \pm 0.00$ & $8.05 \pm 0.13$ & $0.66 \pm 0.11$ & $5.15 \pm 1.08$ & $2,190 \pm 1,152$ \\
\hline & Day 14 & $7.50 \pm 0.02$ & $7.79 \pm 0.28$ & $0.61 \pm 0.05$ & $4.02 \pm 0.04$ & $1,421 \pm 651$ \\
\hline
\end{tabular}

in NATT than the other three groups ( $\mathrm{p}<0.05$ ). No significant differences were found between any other treatment combinations (Appendix F).

PAH concentrations differed significantly among the treatments $(\mathrm{p}<0.05)$. The concentrations of PAHs in the treatments were much higher in spring than in winter (Table 1). The PAH concentrations were lowest in the control and ISB, which did not differ significantly, but were significantly lower than the PAH concentrations in DISP and NATT $(\mathrm{p}<0.05)$. Additionally, the concentrations of PAHs in DISP and NATT also were significantly different $(\mathrm{p}<0.05)$ (Table 2; Appendix F). Detailed information on the composition and concentration of PAHs and alkylated PAHs can be found in Appendix D.

\subsection{Biomass of microorganisms in winter}

Bacteria and heterotrophic nanoflagellates (HNF) exhibited logistic increase in their biomass in all four treatments, with a lag period of 4 days observed in the bacterial population (Fig. 2A, C). Biomasses of bacteria and HNF differed significantly among treatments $(\mathrm{p}<0.05$; Table 3). The biomasses of bacteria in the control and DISP were significantly higher than the biomasses in ISB and NATT ( $p<0.05$ ). The differences in the bacterial biomasses between the control and DISP and between ISB and NATT were not significant. Significantly higher biomass of HNF occurred in the controls than in the other three treatments $(\mathrm{p}<0.05)$. The differences in biomass of HNF among ISB, DISP, and NATT were not significant (Appendix E).

Dinoflagellates increased slowly in all treatments (Fig. 2E), with no significant differences in the biomass among groups (Table 3). Ciliate populations did not increase in any treatments (Fig. 2G), with comparable biomasses in all treatments (Table 3; Appendix E).

Photosynthetic picoplankton, nanoplankton, and diatoms exponentially increased in number, with a long (6-8 days) lag period (Fig. 3A, C, E, G); however, biomass differences were not significant among the treatments (Table 3; Appendix E). The observed accumulation of phytoplankton biomass in all treatments was also supported by the increases of chlorophyll- $a$ (Fig. 3G).

\subsection{Biomass of organisms in spring}

The biomass of bacteria increased exponentially at first in all treatments, but after 6-10 days the biomass continually decreased until the end of the experiment (Fig. 2B). Bacterial biomasses differed significantly among the treatments $(\mathrm{p}<0.05$; Table 4$)$. The bacterial biomass in the control group was significantly lower than in the oil treatments $(p<0.05)$. Differences in bacterial biomass were also significant between all the treatment pairs ( $\mathrm{p}<0.05$; Appendix F), with the highest biomass found in ISB, followed by NATT and DISP, and finally by the control.
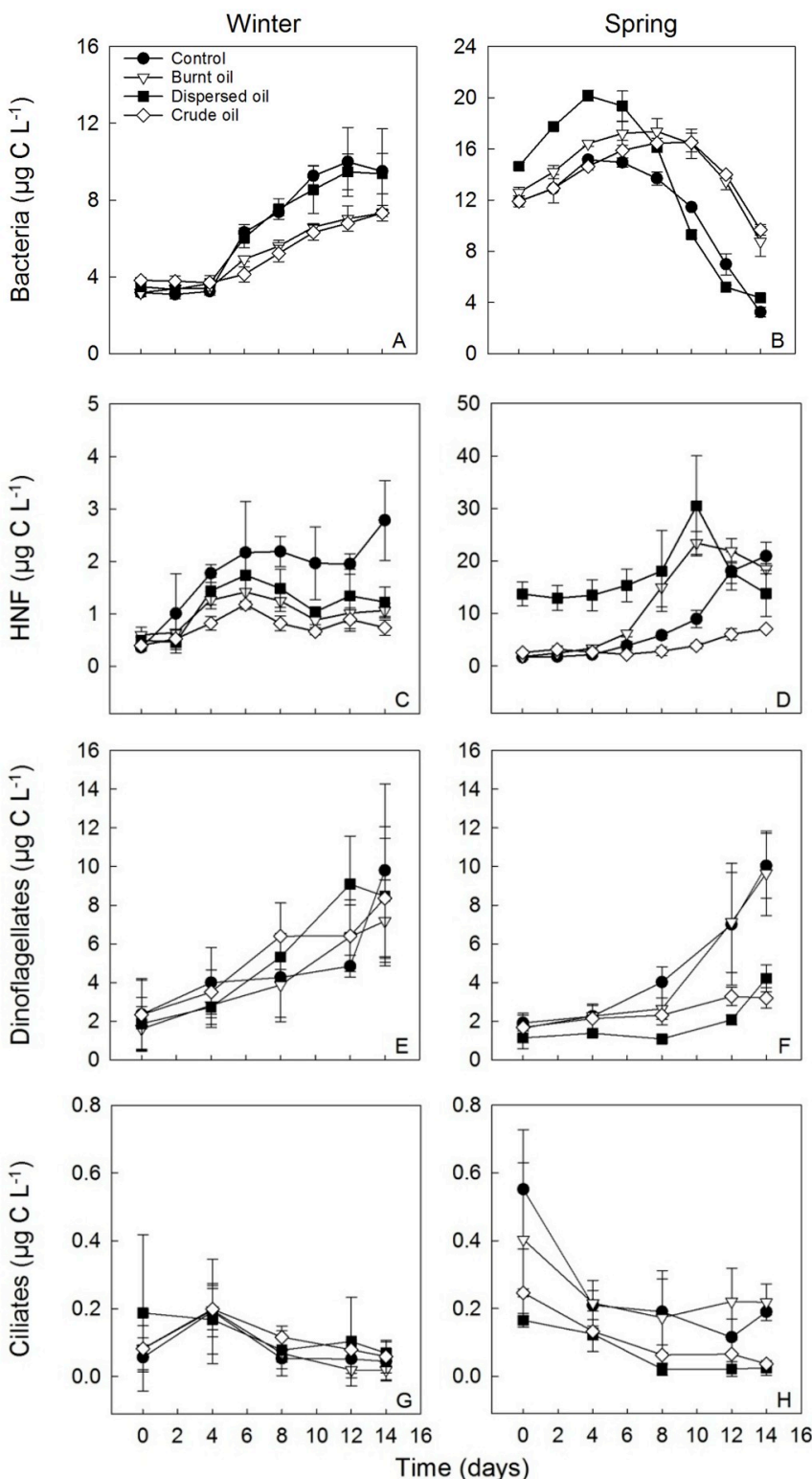

Fig. 2. The mean biomass $\left(\mu \mathrm{C} \mathrm{L} \mathrm{L}^{-1}\right)$ of (A-B) bacteria, (C-D) HNF, (E-F) dinoflagellates, and (G-H) ciliates over exposure duration time (days) in the control, burnt oil, dispersed oil, and crude oil treatments in winter (left) and spring (right). Error bars represent \pm SD. Note that the Y-axis values may differ. 
Table 3

The overall effects of burnt oil (ISB), dispersed oil (DISP), and crude oil (NATT) treatments on organisms in winter, based on the differences between the computed means of the total biomass of organisms in the treatments versus the control. NS - the biomass of organisms in the particular oil treatment was not significantly different from the control. Negative - the biomass of organisms was lower than the control $(\mathrm{p}<0.05)$.

\begin{tabular}{llll}
\hline WINTER & & & \\
\hline Organisms & ISB & DISP & NATT \\
\hline Bacteria & Negative & NS & Negative \\
HNF & Negative & Negative & Negative \\
Dinoflagellates & NS & NS & NS \\
Ciliates & NS & NS & NS \\
Picophytoplankton & NS & NS & NS \\
Nanophytoplankton & NS & NS & NS \\
Diatoms & NS & NS & NS \\
\hline
\end{tabular}

The biomasses of heterotrophic nanoflagellates increased in all four treatments (Fig. 2D), and were significantly different among the groups ( $p<0.05$; Table 4). The biomasses of HNF in the control and ISB were significantly lower than in DISP $(\mathrm{p}<0.05)$, but significantly higher than the biomass in NATT ( $\mathrm{p}<0.05)$. The biomasses in the control and ISB did not differ significantly (Appendix F). The biomass of HNF was highest in DISP, followed by the control and ISB, and finally by NATT.

The biomasses of dinoflagellates differed significantly among the treatments ( $\mathrm{p}<0.05$; Fig. 2F; Table 4). The biomasses in the control and ISB were significantly higher than the biomasses in DISP and NATT $(\mathrm{p}<0.05)$; however, the biomass differences were not significant in either pair (Appendix F).

Ciliate biomasses decreased during the first four days in all four treatments and then stabilized in the control and ISB, but continued to decrease in DISP and NATT (Fig. 2H). The ciliate biomasses in the control and ISB were significantly higher than those in DISP and NATT $(\mathrm{p}<0.05)$. No significant differences in biomass were found between the control and ISB or between DISP and NATT.

The biomasses of picophytoplankton in the control and ISB increased exponentially during the first week, but then decreased until the end of the experimental period (Fig. 3B); however, the biomasses did not differ significantly between the two groups (Table 4). On the other hand, the picophytoplankton populations in DISP and NATT did not increase and differences between the biomass in the two groups were not significant (Table 4). The picophytoplankton biomasses in the control and ISB were significantly higher than those in DISP and NATT ( $\mathrm{p}<0.05$; Appendix F).

The biomasses of nanophytoplankton differed significantly among the treatment groups ( $p<0.05$; Fig. 3D; Table 4). The biomass in the control group was significantly higher than those in the oil treatments $(p<0.05)$. Significant differences in the nanophytoplankton biomasses were also observed between all the other treatment pairs ( $\mathrm{p}<0.05$ ), except for DISP-NATT (Appendix F). The highest biomass was found in the control, followed by ISB and, finally, by DISP and NATT.

Diatom biomasses differed significantly between the treatments ( $p<0.05$; Fig. 3F; Table 4). The highest biomass was observed in ISB, which was significantly higher than those in the other three treatments $(\mathrm{p}<0.05)$. No significant differences were observed between any other treatment pair (Appendix F). The observed differences in the phytoplankton biomass between the treatments were supported by the chlorophyll- $a$ measurements (Fig. $3 \mathrm{H}$ ).


Time (days)

Fig. 3. The mean biomass $\left(\mu \mathrm{C} \mathrm{C} \mathrm{L}^{-1}\right)$ of (A-B) picophytoplankton, (C-D) nanophytoplankton, and (E-F) diatoms, and (G-H) the chlorophyll- $a$ concentration $\left(\mu \mathrm{g} \mathrm{L}^{-1}\right)$ over exposure duration time (days) in the control, burnt oil, dispersed oil, and crude oil treatments in winter (left) and spring (right). Error bars represent $\pm \mathrm{SD}$. Note that the Y-axis values may differ.

\section{Discussion}

Our study investigated the effects of exposure history to oil and oil residues on the Arctic marine microorganisms. The treatments were chosen to simulate an actual oil spill and subsequent application of different response technologies, specifically, application of chemical dispersant, in situ burning of crude oil, and natural attenuation of crude oil. We demonstrated pronounced seasonal differences in the effects of investigated oil spill response technologies on the biomass of the Arctic marine microorganisms. Although the impacts of PAHs in winter were 
Table 4

The overall effects of burnt oil (ISB), dispersed oil (DSIP), and crude oil (NATT) treatments on organisms in spring, based on the differences between the computed means of the total biomass of organisms in the treatments versus the control. NS - the biomass of organisms in the particular oil treatment was not significantly different from the control. Negative - the biomass of organisms was lower than the control ( $p<0.05$ ). Positive - the biomass of organisms was higher than the control ( $\mathrm{p}<0.05)$.

\section{SPRING}

\begin{tabular}{llll}
\hline Organism & ISB & DISP & NATT \\
\hline Bacteria & Positive & Positive & Positive \\
HNF & NS & Positive & Negative \\
Dinoflagellates & NS & Negative & Negative \\
Ciliates & NS & Negative & Negative \\
Picophytoplankton & NS & Negative & Negative \\
Nanophytoplankton & Negative & Negative & Negative \\
Diatoms & Positive & NS & NS \\
\hline
\end{tabular}

low (Table 3), the actual effects of oil treatments on the organisms were merely delayed. When sea ice is present, the oil gets encapsulated in the ice shortly after spillage (Fingas and Hollebone, 2003) and the impacts on the pelagic organisms are observed only when the pollutants are released from the melting ice (Table 4). Importantly, during the mesocosm campaign, Van Mijenfjorden was an industrial fjord with a coal mine that for years (1917-1921 and 1925-2016) was exposed to coal dust contamination and several small oil spills in relation to the coal industry (Statsarkivet 1998). Thus, the air- and sea-borne pollution from the coal mine activities may explain the relatively high concentrations of PAHs measured in our control mesocosms (Tables 1 and 2). Consequently, organisms in the fjord may be adapted to this chronic contaminant exposure; therefore, the results of our study may underestimate the impacts of these oil spill remediation technologies on pristine Arctic environments.

Overall, low concentrations of PAHs were measured in the water column in winter (Table 1). Although the concentrations of PAHs in DISP and NATT treatments were low, the amounts were six-times higher than the control and ISB treatments. The low amounts of PAHs in ISB probably resulted from substantial removal of crude oil during the incineration (Appendix C and D) (Potter and Buist, 2010) and rapid encapsulation of the remaining compounds in the ice (Petrich et al., 2013).

Generally, over the course of incubation microcosm experiments, the nutrient concentrations decreased and the $\mathrm{pH}$ increased in all four treatments (Table 1), indicating similar levels of microbial activity in the different treatments (Hofslagare et al., 1983; Parsons et al., 1984; Siron et al., 1996). This was supported by the observations of comparable biomasses of dinoflagellates, ciliates (Fig. 2E and G) and phytoplankton (also supported by chlorophyll- $a$ measurements; Fig. 3) among the treatments; however, there were some discrepancies in the bacterial and HNF biomasses in the oil groups relative to the control (Fig. 2A and C; Table 3). Our results showed that bacterial biomasses were considerably lower in ISB and NATT treatments than in the control and DISP (Fig. 2A). This could be explained by lower grazing pressure on bacteria in the control and DISP treatments; however, that probably was not true in our case because the biomass of HNF was the highest in the controls (Fig. 2C), suggesting that the bacterial population in the control treatment would have experienced the highest grazing mortality. In addition, because the biomasses of microzooplankton (dinoflagellates and ciliates) were similar in all treatments (Fig. 2E and G) grazing pressure cannot explain the differences between the HNF biomasses in the oil treatments and the control. Thus, our results suggest that even low concentrations of PAHs in the water $\left(0.6 \mu \mathrm{g} \mathrm{L}^{-1}\right.$; Table 1$)$ might affect the growth of some bacteria and HNF from the winter populations. This conclusion, however, contrasts with other studies showing enhanced growth of bacteria and, subsequently, $\mathrm{HNF}$ in various oil treatments even at PAH concentrations as high as $10 \mathrm{~g} \mathrm{~L}^{-1}$ (Delille and Siron, 1993; Jung et al., 2010; Ortmann et al., 2012).

In spring, higher air temperatures and formation of brine channels in the sea ice increased the release of PAHs into the water. Importantly, the concentrations of PAHs measured in the mesocosms in spring did not reflect the total concentration of PAHs introduced into the mesocosms, because most of PAHs were still trapped inside the sea ice. Nevertheless, the PAH concentrations measured in DISP and NATT treatments were up to two orders of magnitude higher than in the control and ISB (Table 2). Consequently, these higher concentrations of PAHs in the DISP and NATT treatments resulted in approximately $50 \%$ lower biomass of the microorganisms in the incubation microcosms compared to the control group (Table 4).

The DISP treatment negatively affected biomasses of microzooplankton and small phytoplankton, but stimulated bacteria and HNF populations (Table 4; Figs. 2 and 3). These observations agree with earlier studies, which demonstrated that dispersed oil treatment resulted in enhanced growth of bacteria and HNF but depressed the growth of microzooplankton (Parsons et al., 1984; Ortmann et al., 2012). The NATT treatment negatively affected biomasses of microzooplankton, HNF, and small phytoplankton, but stimulated bacterial growth (Table 4; Figs. 2 and 3). Similarly, bacterial production increased and microzooplankton abundance decreased in the water-soluble fraction of diesel fuel oil treatment, and conversely, production of HNF increased (Koshikawa et al., 2007). Overall, the high numbers of bacteria in oil treatments may imply that some bacteria can grow and utilize oil compounds as substrate, whereas the stimulatory effects of oil on $\mathrm{HNF}$ are probably related to indirect effects, specifically increased abundance of bacteria and reduced grazing pressure. Oil compounds can cause the loss of cell mobility (Soto et al., 1975), which could lead to impaired feeding activity of motile microzooplankton and their low production in polluted environments (Fig. $2 \mathrm{~F}$ and $\mathrm{H}$ ). Various studies have demonstrated harmful effects of oil compounds on the physiology of phytoplankton cells. For example, both crude oil and chemically dispersed oil negatively affected the cell membrane genes in phytoplankton (Hook and Osborn, 2012). Additionally, oil compounds can accumulate in the cell membrane, subsequently changing its structural and functional properties and irreversibly damaging the cell surface (Sikkema et al., 1995). Moreover, oil compounds also can interfere with photosynthetic processes (González et al., 2009), causing chloroplasts to shrink (Tukaj et al., 1998) or the loss of other pigments (Ozhan et al., 2014 and references therein), which all could affect small phytoplankton growth. Finally, our results indicated that DISP and NATT treatments did not significantly affect diatom numbers (Fig. 3F). González et al. (2009) reported that small diatoms were stimulated by the water-soluble fraction of oil, while large diatoms were negatively affected by high, but not by low, oil concentrations. This could indicate that size of diatoms may be important (Ozhan et al., 2014), with small diatoms being more tolerant to oil pollution than large ones (González et al., 2009). Because we lack data on diatom sizes, and because diatoms in our study were not significantly affected by high concentrations of PAHs, we can speculate that small and possibly more resilient diatoms predominated in the measured biomass.

By contrast, the ISB treatment had no effect on the biomasses of microzooplankton, HNF, and picophytoplankton, but stimulated bacteria and diatom populations (Figs. 2 and 3). Again, the increased abundance of bacteria suggested that some bacteria may be able to degrade and utilize certain oil compounds from the increased carbon 
pool in the ISB treatment. Similarly, low concentrations of PAHs were tolerated and even stimulated the growth of diatoms, which agrees with previous observations (González et al., 2009). By contrast, the treatment negatively affected nanophytoplankton (Fig. 3D), indicating that some oil compounds, even at low concentrations, adversely affected biomass of nanophytoplankton. This result, however, contrasts with those from earlier studies, where lower tolerance to oil by picophytoplankton, but not nanophytoplankton, was observed, which was attributed to their smaller size and larger surface to volume ratio (Sargian et al., 2007; Echeveste et al., 2010).

The differences in microbial activity among the treatments were also reflected in differences in nutrients utilized during the experiments. Overall, the concentrations of nutrients decreased in all treatments but stayed significantly higher in DISP and NATT than the control (Table 2). Low chlorophyll- $a$ concentrations measured in these treatments could explain low utilization of nutrients (Fig. $3 \mathrm{H}$ ). Because the lowest nutrient concentrations were measured in the control, the low numbers of organisms in DISP and NATT treatments cannot be explained by the nutrient limitation.

The effects of oil spill response technologies on marine microorganisms are here documented as changes in the structure and biomass of the major functional groups. Our study concludes that application of ISB, DISP and NATT may promote biomasses of bacteria and heterotrophic nanoflagellates, while the use of DISP and NATT probably will have adverse effects on phytoplankton and microzooplankton (Figs. 2 and 3). Due to approximately $50 \%$ lower biomass of microorganisms in DISP and NATT and consequently altered structure compared to the controls, disruptions in the transfer of energy from the primary producers to the higher trophic levels may be expected in oil affected areas.

\section{Author contributions}

Marina Pančić: developed the protocols, conducted the experiments, analyzed the biological samples, analyzed the data, and wrote the manuscript.

Eva Köhler: conducted the experiments, analyzed the biological samples, discussed the results, and revised the manuscript.

Maria Lund Paulsen: performed the nutrient analysis, assisted with flow cytometry gating, discussed the results, and revised the manuscript.

Kirstine Toxværd: acquired the funding, and revised the manuscript.

Stéphane Le Floch: performed the PAH analysis.

Camille Lacroix: performed the PAH analysis.

Morten Hjorth: developed the project idea, acquired the funding, supervised the project, and revised the manuscript.

Torkel Gissel Nielsen: developed the project idea, acquired the funding, supervised the project, and revised the manuscript.

\section{Author declaration}

We wish to draw the attention of the Editor to the following facts that may be considered as potential conflicts of interest and to significant financial contributions to this work:
- The project was co-funded by the International Association of Oil and Gas Producers, Arctic Oil Spill Response Technology - Joint Industry Programme. The role of this funding source was in study design and in the decision to submit the article for publication. The funding source had no involvement in data analysis and data interpretation, or writing the article.

- Some of the authors are employed by private consultancies (K. Toxværd and M. Hjorth at COWI) and private associations (C. Lacroix and S. Le Floch at CEDRE).

We confirm that the manuscript has been read and approved by all named authors and that there are no other people who satisfied the criteria for authorship but are not listed. We confirm that the order of authors listed in the manuscript has been approved by all of us.

We confirm that we have given due consideration to the protection of intellectual property associated with this work and that there are no impediments to publication, including the timing of publication, with respect to intellectual property. We confirm that we have followed the regulations of our institutions concerning intellectual property.

We further confirm that any aspect of the work covered in this manuscript that has involved either experimental animals or human patients has been conducted with the ethical approval of all relevant bodies and that such approvals are acknowledged within the manuscript.

We understand that the Corresponding Author is the sole contact for the Editorial process (including Editorial Manager and direct communications with the office). Corresponding Author is responsible for communicating with the other authors about progress, submissions of revisions and final approval of proofs. We confirm that we have provided a current, correct email address which is accessible by the Corresponding Author and which has been configured to accept email from tgin@aqua.dtu.dk.

\section{Acknowledgements}

This work was supported by COWIfonden - The Innovation Fund Denmark (\#4135-00045, 2014), and the members of the International Association of Oil and Gas Producers - Arctic Oil Spill Response Technology - Joint Industry Programme (JIP). The Principals of the JIP are: BP Exploration Operating Company, Chevron Canada Limited, ConocoPhillips Corporation, Eni E \& P, ExxonMobil Joint Research Limited, North Caspian Operating Company, Shell International Exploration and Production BV, Statoil Petroleum AS, and Total E \& P Recherche et Développement. Field work was approved by the Governor of Svalbard (\#RIS ID 10026, 2014). We would like to thank Lionel Camus for coordinating the field work, and Dr. Mathijs Smit for his constructive comments on the manuscript. Sea Pen Scientific Writing provided editing services. We would in particular like to thank Carl Ballantine for providing vital logistic framework for field experiments, and also the University Center in Svalbard for allowing us to use their research facilities. 
की

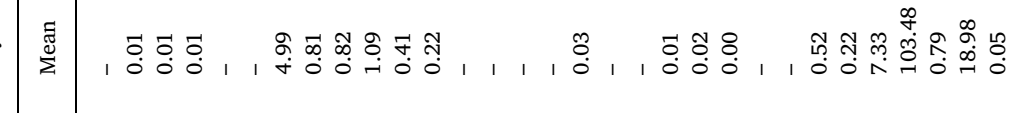

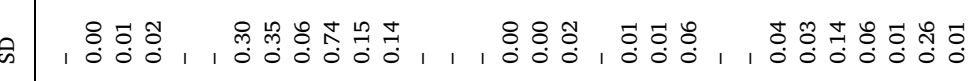



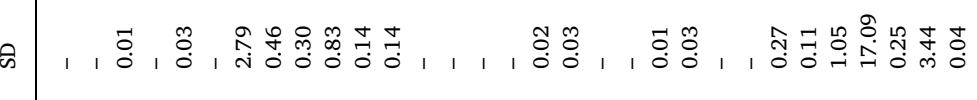

通

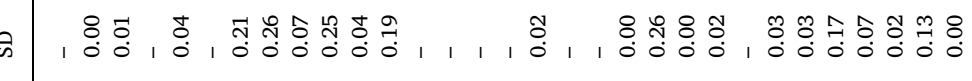

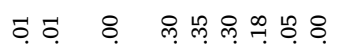

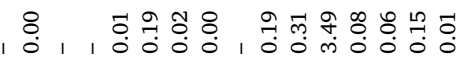

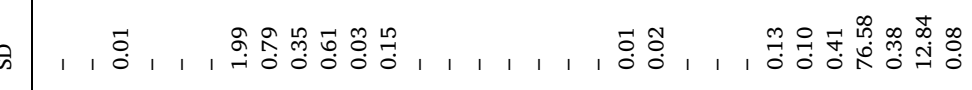

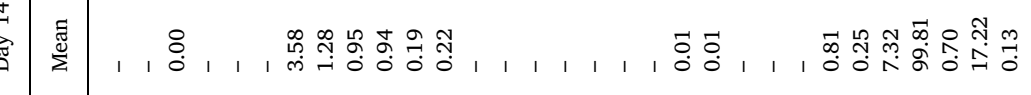

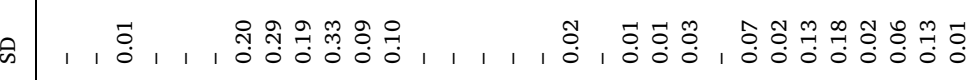



,

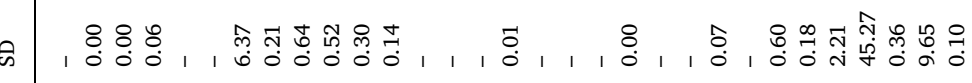



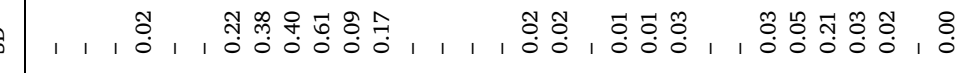

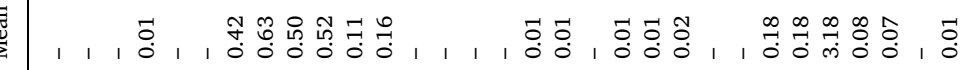

है จ

เ

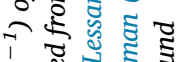

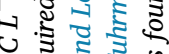



की

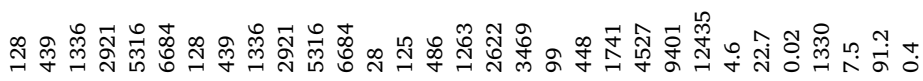

政

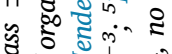

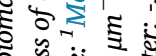

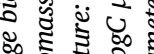

: 8 is

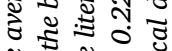













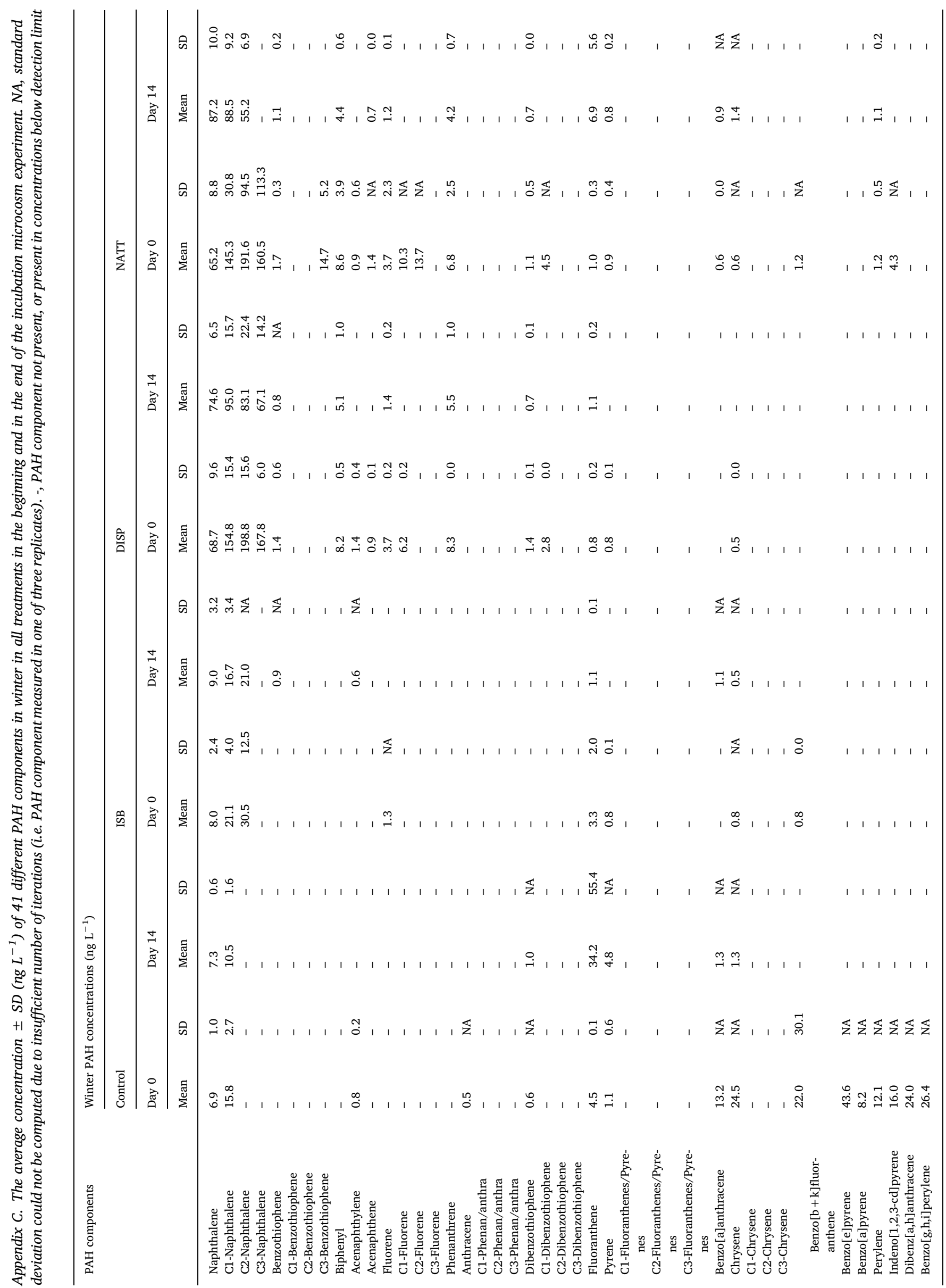




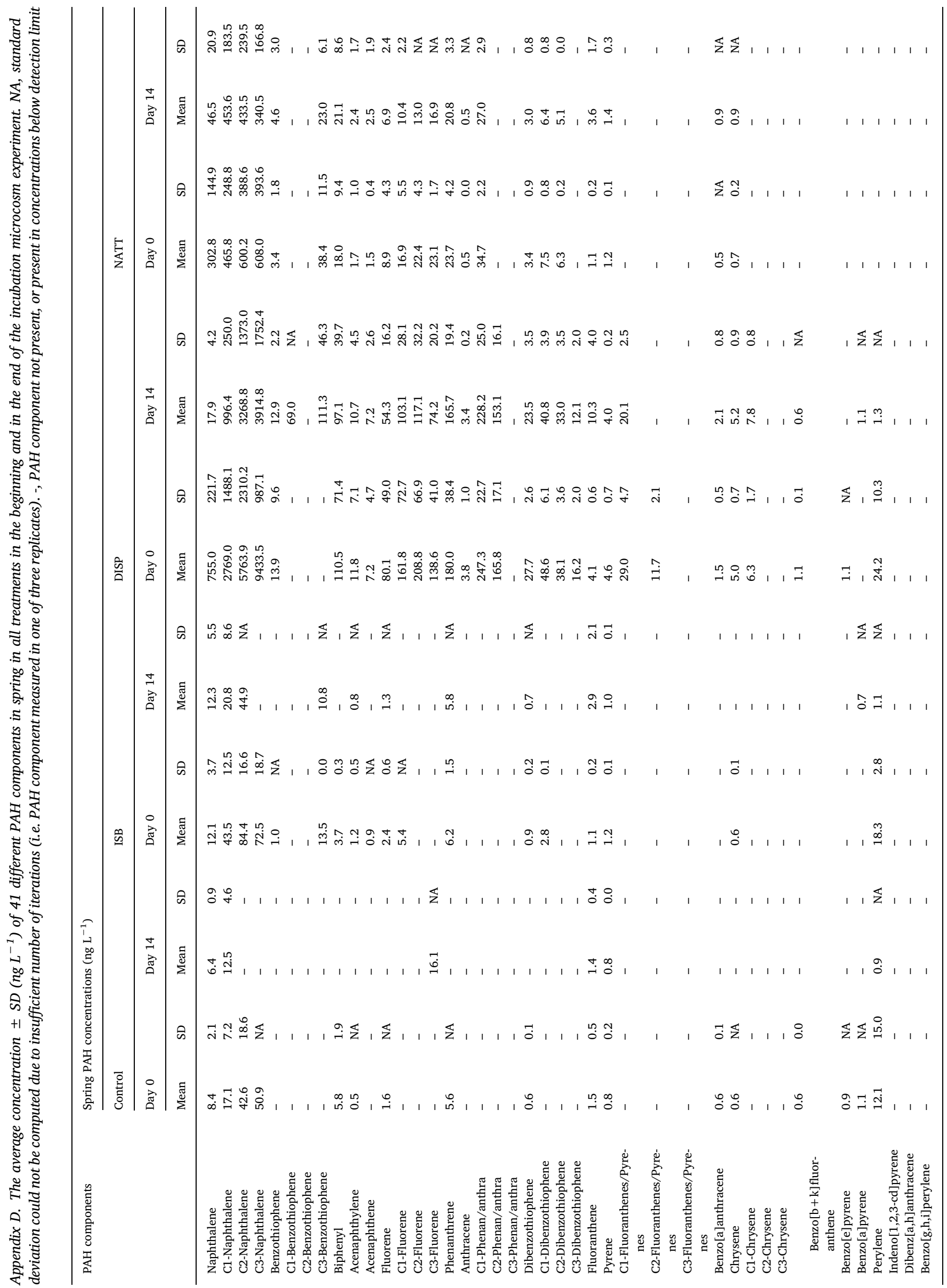


Appendix E. Results of ANOVAs and pairwise comparisons of pooled standard deviations of $p H$, phosphate, silicate, nitrate, and PAH concentrations, and biomasses of bacteria, HNF, dinoflagellates, ciliates, pico- and nano-phytoplankton, and diatoms in winter. Significant differences are indicated in bold

\begin{tabular}{|c|c|c|c|c|c|}
\hline Parameters in winter & ANOVA & Pairwi & & & \\
\hline \multirow[t]{4}{*}{$\mathrm{pH}$} & $\mathrm{F}(3,8)=1.488$ & & Control & ISB & DISP \\
\hline & $\mathrm{P}=0.289$ & ISB & 0.38 & - & - \\
\hline & & DISP & 0.38 & 0.82 & - \\
\hline & & NATT & 0.53 & 0.73 & 0.76 \\
\hline \multirow[t]{4}{*}{ Phosphate } & $\mathrm{F}(3,8)=0.506$ & & Control & ISB & DISP \\
\hline & $P=0.689$ & ISB & 0.80 & - & - \\
\hline & & DISP & 0.80 & 0.80 & - \\
\hline & & NATT & 0.80 & 0.80 & 0.80 \\
\hline \multirow[t]{4}{*}{ Silicate } & $\mathrm{F}(3,8)=1.580$ & & Control & ISB & DISP \\
\hline & $P=0.269$ & ISB & 0.66 & - & - \\
\hline & & DISP & 0.71 & 0.51 & - \\
\hline & & NATT & 0.41 & 0.51 & 0.41 \\
\hline \multirow[t]{4}{*}{ Nitrate } & $\mathrm{F}(3,8)=1.488$ & & Control & ISB & DISP \\
\hline & $\mathrm{P}=0.289$ & ISB & 0.88 & - & - \\
\hline & & DISP & 0.60 & 0.60 & - \\
\hline & & NATT & 0.36 & 0.36 & 0.60 \\
\hline \multirow[t]{4}{*}{$\mathrm{PAH}$} & $\mathrm{F}(3,8)=46.217$ & & Control & ISB & DISP \\
\hline & $\mathrm{P}=2.131 \mathrm{e}-05$ & ISB & 0.60 & - & - \\
\hline & & DISP & 7.1e-05 & $7.1 \mathrm{e}-05$ & - \\
\hline & & NATT & 8.7e-05 & $7.1 \mathrm{e}-05$ & 0.60 \\
\hline \multirow[t]{4}{*}{ Bacteria } & $\mathrm{F}(3,8)=9.415$ & & Control & ISB & DISP \\
\hline & $P=0.005$ & ISB & 0.01 & - & - \\
\hline & & DISP & 0.89 & 0.01 & - \\
\hline & & NATT & 0.01 & 0.89 & 0.01 \\
\hline \multirow[t]{4}{*}{$\mathrm{HNF}$} & $\mathrm{F}(3,8)=8.166$ & & Control & ISB & DISP \\
\hline & $P=0.008$ & ISB & 0.02 & - & - \\
\hline & & DISP & 0.03 & 0.54 & - \\
\hline & & NATT & 0.009 & 0.31 & 0.15 \\
\hline \multirow[t]{4}{*}{ Dinoflagellates } & $\mathrm{F}(3,8)=0.254$ & & Control & ISB & DISP \\
\hline & $\mathrm{P}=0.856$ & ISB & 0.95 & - & - \\
\hline & & DISP & 0.95 & 0.95 & - \\
\hline & & NATT & 0.95 & 0.95 & 0.95 \\
\hline \multirow[t]{4}{*}{ Ciliates } & $\mathrm{F}(3,8)=1.802$ & & Control & ISB & DISP \\
\hline & $\mathrm{P}=0.225$ & ISB & 0.91 & - & - \\
\hline & & DISP & 0.31 & 0.31 & - \\
\hline & & NATT & 0.39 & 0.39 & 0.67 \\
\hline \multirow[t]{4}{*}{ Pico-phytoplankton } & $F(3,8)=3.239$ & & Control & ISB & DISP \\
\hline & $\mathrm{P}=0.082$ & ISB & 0.65 & - & - \\
\hline & & DISP & 0.15 & 0.20 & - \\
\hline & & NATT & 0.15 & 0.17 & 0.78 \\
\hline \multirow[t]{4}{*}{ Nano-phytoplankton } & $\mathrm{F}(3,8)=0.234$ & & Control & ISB & DISP \\
\hline & $\mathrm{P}=0.870$ & ISB & 0.96 & - & - \\
\hline & & DISP & 0.96 & 0.96 & - \\
\hline & & NATT & 0.96 & 0.96 & 0.96 \\
\hline \multirow[t]{4}{*}{ Diatoms } & $F(3,8)=0.348$ & & Control & ISB & DISP \\
\hline & $\mathrm{P}=0.792$ & ISB & 0.91 & - & - \\
\hline & & DISP & 0.91 & 0.91 & - \\
\hline & & NATT & 0.91 & 0.93 & 0.91 \\
\hline
\end{tabular}


Appendix F. Results of ANOVAs and pairwise comparisons of pooled standard deviations of $p H$, phosphate, silicate, nitrate, and PAH concentrations, and biomasses of bacteria, HNF, dinoflagellates, ciliates, pico- and nano-phytoplankton, and diatoms in spring. Significant differences are indicated in bold

\begin{tabular}{|c|c|c|c|c|c|}
\hline Parameters in spring & ANOVA & Pairwis & & & \\
\hline $\mathrm{pH}$ & $\begin{array}{l}F(3,8)=55.7 \\
P=1.053 e-05\end{array}$ & $\begin{array}{l}\text { ISB } \\
\text { DISP } \\
\text { NATT }\end{array}$ & $\begin{array}{l}\text { Control } \\
0.0001 \\
8 \mathrm{e}-06 \\
0.0003\end{array}$ & $\begin{array}{l}\text { ISB } \\
- \\
\mathbf{0 . 0 0 2} \\
0.26\end{array}$ & $\begin{array}{l}\text { DISP } \\
- \\
- \\
0.0006\end{array}$ \\
\hline Phosphate & $\begin{array}{l}F(3,8)=101.14 \\
P=\mathbf{1 . 0 6 1 e - 0 6}\end{array}$ & $\begin{array}{l}\text { ISB } \\
\text { DISP } \\
\text { NATT }\end{array}$ & $\begin{array}{l}\text { Control } \\
0.004 \\
0.002 \\
1.1 \mathrm{e}-06\end{array}$ & $\begin{array}{l}\text { ISB } \\
- \\
0.44 \\
4.9 \mathrm{e}-06\end{array}$ & $\begin{array}{l}\text { DISP } \\
- \\
- \\
5.4 \mathrm{e}-06\end{array}$ \\
\hline Silicate & $\begin{array}{l}F(3,8)=1.107 \\
P=0.0009\end{array}$ & $\begin{array}{l}\text { ISB } \\
\text { DISP } \\
\text { NATT }\end{array}$ & $\begin{array}{l}\text { Control } \\
0.62 \\
0.47 \\
\mathbf{0 . 0 0 2} \\
\end{array}$ & $\begin{array}{l}\text { ISB } \\
- \\
0.62 \\
\mathbf{0 . 0 0 2}\end{array}$ & $\begin{array}{l}\text { DISP } \\
- \\
- \\
\mathbf{0 . 0 0 2}\end{array}$ \\
\hline Nitrate & $\begin{array}{l}F(3,8)=276.64 \\
P=\mathbf{2 . 0 3 7 e - 0 8}\end{array}$ & $\begin{array}{l}\text { ISB } \\
\text { DISP } \\
\text { NATT }\end{array}$ & $\begin{array}{l}\text { Control } \\
0.13 \\
\mathbf{0 . 0 0 0 2} \\
\mathbf{2 . 9 e - 0 8}\end{array}$ & $\begin{array}{l}\text { ISB } \\
- \\
0.0008 \\
2.9 \mathrm{e}-08\end{array}$ & $\begin{array}{l}\text { DISP } \\
- \\
- \\
1.4 \mathrm{e}-07\end{array}$ \\
\hline $\mathrm{PAH}$ & $\begin{array}{l}F(3,8)=210.09 \\
P=6.043 e-08\end{array}$ & $\begin{array}{l}\text { ISB } \\
\text { DISP } \\
\text { NATT }\end{array}$ & $\begin{array}{l}\text { Control } \\
0.91 \\
\mathbf{8 . 2 e - 0 8} \\
\mathbf{0 . 0 5}\end{array}$ & $\begin{array}{l}\text { ISB } \\
- \\
8.2 \mathrm{e}-08 \\
0.05\end{array}$ & $\begin{array}{l}\text { DISP } \\
- \\
- \\
1.2 \mathrm{e}-07\end{array}$ \\
\hline Bacteria & $\begin{array}{l}F(3,8)=73.009 \\
P=3.741 \mathrm{e}-06\end{array}$ & $\begin{array}{l}\text { ISB } \\
\text { DISP } \\
\text { NATT } \\
\end{array}$ & $\begin{array}{l}\text { Control } \\
4.3 \mathrm{e}-06 \\
4.3 \mathrm{e}-05 \\
9.1 \mathrm{e}-06 \\
\end{array}$ & $\begin{array}{l}\text { ISB } \\
- \\
0.002 \\
0.05\end{array}$ & $\begin{array}{l}\text { DISP } \\
- \\
- \\
\mathbf{0 . 0 3}\end{array}$ \\
\hline HNF & $\begin{array}{l}F(3,8)=21.099 \\
P=0.0004\end{array}$ & $\begin{array}{l}\text { ISB } \\
\text { DISP } \\
\text { NATT }\end{array}$ & $\begin{array}{l}\text { Control } \\
0.07 \\
\mathbf{0 . 0 0 2} \\
\mathbf{0 . 0 5}\end{array}$ & $\begin{array}{l}\text { ISB } \\
- \\
\mathbf{0 . 0 2} \\
\mathbf{0 . 0 0 4}\end{array}$ & $\begin{array}{l}\text { DISP } \\
- \\
- \\
\mathbf{0 . 0 0 0 4}\end{array}$ \\
\hline Dinoflagellates & $\begin{array}{l}F(3,8)=19.703 \\
P=0.0005\end{array}$ & $\begin{array}{l}\text { ISB } \\
\text { DISP } \\
\text { NATT }\end{array}$ & $\begin{array}{l}\text { Control } \\
0.46 \\
\mathbf{0 . 0 0 1} \\
\mathbf{0 . 0 0 2}\end{array}$ & $\begin{array}{l}\text { ISB } \\
- \\
0.002 \\
\mathbf{0 . 0 0 4}\end{array}$ & $\begin{array}{l}\text { DISP } \\
- \\
- \\
0.35\end{array}$ \\
\hline Ciliates & $\begin{array}{l}F(3,8)=20.075 \\
P=0.0004\end{array}$ & $\begin{array}{l}\text { ISB } \\
\text { DISP } \\
\text { NATT }\end{array}$ & $\begin{array}{l}\text { Control } \\
0.86 \\
\mathbf{0 . 0 0 1} \\
\mathbf{0 . 0 0 2}\end{array}$ & $\begin{array}{l}\text { ISB } \\
- \\
0.001 \\
0.002\end{array}$ & $\begin{array}{l}\text { DISP } \\
- \\
- \\
0.28\end{array}$ \\
\hline Pico-phytoplankton & $\begin{array}{l}F(3,8)=331.64 \\
P=9.931 e-09\end{array}$ & $\begin{array}{l}\text { ISB } \\
\text { DISP } \\
\text { NATT }\end{array}$ & $\begin{array}{l}\text { Control } \\
0.81 \\
2.8 \mathrm{e}-08 \\
2.8 \mathrm{e}-08\end{array}$ & $\begin{array}{l}\text { ISB } \\
- \\
2.8 \mathrm{e}-08 \\
2.8 \mathrm{e}-08\end{array}$ & $\begin{array}{l}\text { DISP } \\
- \\
- \\
0.96\end{array}$ \\
\hline Nano-phytoplankton & $\begin{array}{l}F(3,8)=52.306 \\
P=1.336 e-05\end{array}$ & $\begin{array}{l}\text { ISB } \\
\text { DISP } \\
\text { NATT }\end{array}$ & $\begin{array}{l}\text { Control } \\
0.0002 \\
2.8 \mathrm{e}-05 \\
1.6 \mathrm{e}-05\end{array}$ & $\begin{array}{l}\text { ISB } \\
- \\
\mathbf{0 . 0 5} \\
\mathbf{0 . 0 0 4}\end{array}$ & $\begin{array}{l}\text { DISP } \\
- \\
- \\
0.12\end{array}$ \\
\hline Diatoms & $\begin{array}{l}F(3,8)=7.436 \\
\mathbf{P}=\mathbf{0 . 0 1}\end{array}$ & $\begin{array}{l}\text { ISB } \\
\text { DISP } \\
\text { NATT }\end{array}$ & $\begin{array}{l}\text { Control } \\
\mathbf{0 . 0 4} \\
0.24 \\
0.65\end{array}$ & $\begin{array}{l}\text { ISB } \\
- \\
0.01 \\
0.03\end{array}$ & $\begin{array}{l}\text { DISP } \\
- \\
- \\
0.37\end{array}$ \\
\hline
\end{tabular}

\section{References}

Abbriano, R.M., et al., 2011. Deepwater Horizon oil spill: a review of the planktonic response. Oceanography 24 (3), 294-301.

Almeda, R., Hyatt, C., Buskey, E.J., 2014. Toxicity of dispersant Corexit 9500A and crude oil to marine microzooplankton. Ecotoxicol. Environ. Saf. 106, 76-85.

Børsheim, K.Y., Bratbak, G., 1987. Cell volume to cell carbon conversion factors for a

bacterivorous Monas sp. enriched from seawater. Mar. Ecol. Prog. Ser. 36, 171-175.

Delille, D., Siron, R., 1993. Effect of dispersed oil on heterotrophic bacterial communities in cold marine waters. Microb. Ecol. 25 (3), 263-273.

Dickins, D.F., 2017. Arctic Oil Spill Response Technology Joint Industry Programme
Synthesis Report. Arctic Response Technology JIP.

Echeveste, P., Agustí, S., Dachs, J., 2010. Cell size dependent toxicity thresholds of polycyclic aromatic hydrocarbons to natural and cultured phytoplankton populations. Environ. Pollut. 158 (1), 299-307.

Fingas, M.F., Hollebone, B.P., 2003. Review of behaviour of oil in freezing environments. Mar. Pollut. Bull. 47 (9-12), 333-340.

Gautier, D.L., et al., 2009. Assessment of undiscovered oil and gas in the Arctic. Science 324 (5931), 1175-1179.

González, J., et al., 2009. Effect of a simulated oil spill on natural assemblages of marine phytoplankton enclosed in microcosms. Estuar. Coast Shelf Sci. 83 (3), 265-276.

Harayama, S., Kasai, Y., Hara, A., 2004. Microbial communities in oil-contaminated seawater. Curr. Opin. Biotechnol. 15 (3), 205-214. 
Harrison, P.J., et al., 1986. The effects of crude oil and Corexit 9527 on marine phytoplankton in an experimental enclosure. Mar. Environ. Res. 18 (2), 93-109.

Hays, G.C., Richardson, A.J., Robinson, C., 2005. Climate change and marine plankton. Trends Ecol. Evol. 20 (6), 337-344.

Hofslagare, O., et al., 1983. A precise potentiometric method for determination of algal activity in an open CO2 system. Plant Cell Environ. 6 (3), 195-201.

Hook, S.E., Osborn, H.L., 2012. Comparison of toxicity and transcriptomic profiles in a diatom exposed to oil, dispersants, dispersed oil. Aquat. Toxicol. 124-125, 139-151. Available at: https://doi.org/10.1016/j.aquatox.2012.08.005.

Jung, S.W., et al., 2010. Effects of crude oil on marine microbial communities in short term outdoor microcosms. J. Microbiol. 48 (5), 594-600.

Koshikawa, H., et al., 2007. Effect of the water-soluble fraction of diesel oil on bacterial and primary production and the trophic transfer to mesozooplankton through a microbial food web in Yangtze estuary, China. Estuarine. Coastal Shelf Sci. 71 (1-2), 68-80.

Landry, M.R., Calbet, A., 2004. Microzooplankton production in the oceans. ICES (Int. Counc. Explor. Sea) J. Mar. Sci. 61 (4), 501-507.

Lee, S., Fuhrman, J.A., 1987. Relationships between biovolume and biomass of naturally derived marine bacterioplankton. Appl. Environ. Microbiol. 53 (6), 1298-1303.

Linden, O., et al., 1987. Effects of oil and oil dispersant on an enclosed marine ecosystem. Environ. Sci. Technol. 21 (4), 374-382.

Little, E.M., Allen, M.B., Wright, F.F., 1972. Field measurement of light penetration through sea ice. Arctic 25 (139), 28-33. Available at: http://www.jstor.org/stable/ 40508023.

Marie, D., et al., 1999. Enumeration of marine viruses in culture and natural samples by flow cytometry. Appl. Environ. Microbiol. 65 (1), 45-52.

Menden-Deuer, S., Lessard, E.J., 2000. Carbon to volume relationships for dinoflagellates, diatoms, and other protist plankton. Limnol. Oceanogr. 45 (3), 569-579.

Murphy, J., Riley, J.P., 1962. A modified single solution method for the determination of phosphate in natural waters. Anal. Chim. Acta 27, 31-36.

Olsen, G.H., et al., 2013. Toxicity data for modeling impacts of oil components in an Arctic ecosystem. Mar. Environ. Res. 90, 9-17.

Ortmann, A.C., et al., 2012. Dispersed oil disrupts microbial pathways in pelagic food webs. PLoS One 7 (7), 1-9.

Oviatt, C., et al., 1982. Low chronic additions of No. 2 fuel oil: chemical behavior, biological impact and recovery in a simulated estuarine environment. Mar. Ecol. Prog. Ser. 9, 121-136.

Ozhan, K., Parsons, M.L., Bargu, S., 2014. How were phytoplankton affected by the deepwater horizon oil spill? Bioscience 64 (9), 829-836.

Parsons, T.R., et al., 1984. An experimental marine ecosystem response to crude oil and Corexit 9527: Part 2 - biological effects. Mar. Environ. Res. 13 (4), 265-275.

Paulsen, M.L., et al., 2015. Winter-spring transition in the subarctic Atlantic: microbial response to deep mixing and pre-bloom production. Aquat. Microb. Ecol. 76 (1), 49-69.

Petrich, C., Karlsson, J., Eicken, H., 2013. Porosity of growing sea ice and potential for oil entrainment. Cold Reg. Sci. Technol. 87, 27-32.

Potter, S., Buist, I., 2010. In situ burning in Arctic and ice-covered waters: tests of fireresistant boom in low boncentrations of drift ice. In: Proceedings 33rd Arctic and Marine Oilspill Program Technical Seminar. Environement Canada, Ottawa, Ontario, pp. 743-754.
Putt, M., Stoecker, D.K., 1989. An experimentally determined carbon:volume ratio for marine "oligotrichous" ciliates from estuarine and coastal waters. Limnol. Oceanogr. 34 (6), 1097-1103.

Sargian, P., et al., 2007. Multiple stressors on an Antarctic microplankton assemblage: water soluble crude oil and enhanced UVBR level at Ushuaia (Argentina). Polar Biol 30 (7), 829-841.

Sargian, P., et al., 2005. Non-synergistic effects of water-soluble crude oil and enhanced ultraviolet-B radiation on a natural plankton assemblage. Mar. Ecol. Prog. Ser. 294, 63-77.

Scott, B.F., Glooschenko, V., 1984. Impact of oil and oil-dispersant mixtures on flora and water chemistry parameters in freshwater ponds. Sci. Total Environ. 35 (2), 169-190.

Sikkema, J., de Bont, J.A., Poolman, B., 1995. Mechanisms of membrane toxicity of hydrocarbons. Microbiol. Rev. 59 (2), 201-222. Available at: http://www.ncbi.nlm. nih.gov/pubmed/7603409.

Siron, R., et al., 1993. Fate and effects of dispersed crude oil under icy conditions simulated in mesocosms. Mar. Environ. Res. 35 (3), 273-302.

Siron, R., Pelletier, E., Roy, S., 1996. Effects of dispersed and adsorbed crude oil on microalgal and bacterial communities of cold seawater. Ecotoxicology 5, 229-251.

Søndergaard, M., 1991. Phototrophic picoplankton in temperate lakes: seasonal abundance and importance along a trophic rradient. Int. Rev. Gesamten Hydrobiol. Hydrogr. 76 (4), 505-522.

Soto, C., et al., 1975. Effect of naphthalene and aqueous crude oil extracts on the green flagellate Chlamydomonas angulosa. I. Growth. Can. J. Bot. 53 (2), 109-117. Available at: https://doi.org/10.1139/b75-017.

Statsarkivet, 1998. Store Norske Spitsbergen Kullkompani AS Arkivkatalog 1916 - 1988. Privatarkiv nr. 73 Statsarkivet Tromsø, Norway.

Strickland, J.D.H., Parsons, T.R., 1972. A Practical Handbook of Seawater Analysis. Fisheries Research Board of Canada 1972.

Toxværd, K., et al., 2018. Effects of oil spill response technologies on the physiological performance of the Arctic copepod Calanus glacialis. Aquat. Toxicol. 199, 65-76.

Tukaj, Z., Bohdanowicz, J., Aksmann, A., 1998. A morphometric and stereological analysis of ultrastructural changes in two Scenedesmus (Chlorococcales, Chlorophyta) strains subjected to diesel fuel oil pollution. Phycologia 35 (5), 388-393.

U.S. Geological Survey, 2009. Circum-Arctic resource appraisal: estimates of undiscovered oil and gas north of the Arctic Circle. Available at: http://energy.usgs. gov/arctic/.

Vargo, G.A., Hutchins, M., Almquist, G., 1982. The effect of low, chronic levels of No. 2 fuel oil on natural phytoplankton assemblages in microcosms. 1. Species composition and seasonal succession. Mar. Environ. Res. 6 (4), 245-264.

Verity, P.G., Lagdon, C., 1984. Relationships between lorica volume, carbon, nitrogen, and ATP content of tintinnids in Narragansett Bay. J. Plankton Res. 6 (5), 859-868.

Wilkinson, J., et al., 2017. Oil spill response capabilities and technologies for ice-covered Arctic marine waters: a review of recent developments and established practices. Ambio 46 (s3), 423-441.

Wood, E.D., Armstrong, F.A.J., Rich, F.A., 1967. Determination of nitrate in seawater by cadmium-copper reduction to nitrate. J. Mar. Biol. Assoc. U. K. 47 (1), 23-31.

Zubkov, M.V., et al., 1998. Picoplanktonic community structure on an Atlantic transect from $50 \mathrm{~N}$ to 50 S. Deep-Sea Res. Part I Oceanogr. Res. Pap. 45 (8), 1339-1355.

Zubkov, M.V., Burkill, P.H., Topping, J.N., 2007. Flow cytometric enumeration of DNAstained oceanic planktonic protists. J. Plankton Res. 29 (1), 79-86. 